\title{
Potential Distribution Modeling and Mapping of Brutian Pine Stands in the Inner Parts of the Middle Black Sea Region in Turkey
}

\author{
Özdemir Şentürk ${ }^{1 *}$, Serkan Gülsoy² İlker Tümer² $^{2}$ \\ ${ }^{1}$ Burdur Mehmet Akif Ersoy University, Gölhisar Vocational School, Gölhisar, Burdur, Turkey \\ ${ }^{2}$ Isparta University of Applied Sciences, Department of Forest Engineering, \\ Division of Soil Science and Ecology, Isparta, Turkey
}

Received: 8 August 2017

Accepted: 2 January 2018

\begin{abstract}
Brutian pine (Pinus brutia Ten.) is one of the most common and precious coniferous tree species in Turkey. Except for its main distribution areas such as the Mediterranean and Aegean regions, brutian pine can be found in isolated areas due to its different forest site factors. Therefore, our aim was to obtain a model and map of this species in the Aydınca District, which is one of these isolated areas. For these purposes, the presence or absence of data of target species was collected from 453 sample plots. Environmental variables - including elevation, slope, heat index, topographic position index, slope position, bedrock types, BIO1, and BIO12 - were selected for generating a model and map of brutian pine via the generalized additive model. The model and map show that BIO1, BIO12, elevation, heat index, and bedrock were the most important explanatory variables. As a result of the obtained model, potential distribution of brutian pine was determined to range from 400 to $806 \mathrm{~m}$ elevation. In addition to this result, climate conditions for brutian pine were areas where the annual mean temperature was $11-12.5^{\circ} \mathrm{C}$ and annual mean precipitation was $428-439 \mathrm{~mm}$. Besides, more suitable areas for brutian pine occurred where the heat index values are higher. Finally, brutian pine preferred limestone, schist, and other bedrock types in the district. In this study especially, climatic features that depend on elevation showed significant influence on potential distribution of brutian pine in Aydınca.
\end{abstract}

Keywords: Aydinca District, Pinus brutia Ten., species distribution model, Turkish red pine

\section{Introduction}

Potential distribution models (PDM) can be defined as equations derived to estimate the appropriate alternative distribution areas in nature using the actual environmental variables in the natural distribution areas of species [1-7]. On one hand one can determine the habitat characteristics of the species through PDM while on the other hand ecology-based information needed for basic concepts such as sustainability, conservation, restoration, and biodiversity can be collected [8-12]. In particular,

*e-mail: osenturk@mehmetakif.edu.tr 
the use of PDMs in forestry enables the implementers to make the right decisions regarding forest operations such as afforestation, improvement of the productivity of the degraded forests, selection of appropriate sites for natural and artificial rejuvenation activities, and ensuring the continuity of forest areas.

Globally, studies on PDM have been conducted on different topics regarding several species, including primarily plants, wild animals, birds, insects, and reptiles [13-17]. On this topic, there are remarkable studies recently conducted in Turkey especially regarding plant species. For example, one of the studies conducted at different times in the Yukarıökdere Natural Conservation Area, which is an important protected zone in Isparta Province, identified the potential distribution of diverse variety of non-wood forest products [18], while another study determined the geographical distribution models of $P$. terebinthus, which is an important medical aromatic plant species [19]. There are also other studies conducted directly on tree species such as Cedrus libani [20], Juniperus excelsa [12], Pinus nigra [21], and Quercus cerris [22-23].

The majority of these studies on tree species mainly focus on primary tree species. This is because there are more common primary tree species in the country and they have a higher economic value. In light of this information, brutian pine (Pinus brutia Ten., also known as Turkish red pine) is one of the most important primary tree species in Turkey's forests from economic and ecological perspectives. Especially since this tree species is heavily used in industrial forest operations, it is the number one species in terms of growing stock ( 270 million $\mathrm{m}^{3}$ ) [24]. Considering its economic contribution, it is important to protect or extend the presence of this species in forests, improve its characteristics, and ensure its sustainability on one hand, while on the other hand it is essential to manage it actively. To achieve this goal, its potential distribution areas depending on habitat characteristics should be identified to ensure its sustainability.

Although there are studies in literature that focus on the ecology of brutian pine [25-27], there is no study conducted so far on the PDM of this species. It is distributed across a very wide area of 5.6 million hectares, mainly in the Mediterranean and Aegean regions, and it also has an isolated distribution area in various micro-climate zones that have Mediterranean climate characteristics [28-29]. One of the important isolated distribution zones of this species is Amasya Forest Directorate, which is located in the inner parts of the Middle Black Sea Region in Turkey. The actual distribution of brutian pine stands in this area is approximately 8,500 ha. There is no doubt that such local areas are of great importance as regards ecosystem diversity and different habitat characteristics; therefore, their restoration and sustainability should be ensured. To achieve this goal, only information about its overall ecology is not sufficient, while there is a need for further information on ecology based on a model regarding the habitat characteristics in these local areas. To this end, our study aimed at modeling and mapping the potential distribution areas of this species in the Aydınca using the generalized additive model.

\section{Material and Methods}

\section{Study Area}

This study was conducted in the Aydınca District, which is on the inner side of the middle Black Sea region in Turkey. The district covers an area of $7,549.3 \mathrm{~km}^{2}$ and ranges from $220 \mathrm{~m}$ to $1,955 \mathrm{~m}$ above sea level. The highest peak is Cami Hill $(1,956 \mathrm{~m})$ in the northeastern part of the study area, which is located within the transition zone that ranges from the inner parts of the middle Black Sea Region in Turkey to central Anatolia, and is surrounded by the Yeşilırmak and Kelkit rivers. The district is characterized by the different parent materials of schist, volcanic sediment, ophiolitic melange, alluvium, limestone, and other bedrock types. Especially while upper areas are composed of schist, limestone, and ophiolitic melange, lower zones are comprised of alluvium and volcanic sediment. In addition to brutian pine, scotch pine (Pinus sylvestris L.), black pine (Pinus nigra Arnold.), crimean juniper (Juniperus excelsa Bieb.), common beech (Fagus orientalis L.), and oaks species are also important tree species in this location. The Aydinca District is located within the transition zone between the middle Black Sea and central Anatolian regions in Turkey. The annual average temperature is $13.6^{\circ} \mathrm{C}$ and the average annual precipitation is $460.3 \mathrm{~mm}$ [30].

\section{Data Collection and Environmental Variables}

Data was collected from 453 sample plots in the study area. Binary data (presence and absence data) of brutian pine were recorded at each sample plot, which is $400 \mathrm{~m}^{2}$. Latitude and longitude, elevation, and slope degree were numerically recorded at each area by using GPS (m), an altimeter (m), and a clinometer (\%), respectively. On the other hand, values of aspect and slope degree were transformed into heat index (HEATIN) by means of the formula HEATIN $=\cos \left(\right.$ aspect $\left.-202.5^{\circ}\right) \times$ tg (slope), where $202.5^{\circ}$ is a value that means the warmest aspect (SSW). This formula's results changed between -1 and 1 [31-32]. Climate predictors were represented by 2 bioclim variables [33], which are annual mean temperature (BIO1) and annual precipitation (BIO12), acquired from the WorldClim database (worldclim.org).

In order to generate the potential distribution model and map of brutian pine, environmental variables were obtained by using geographical information systems (GIS). At first, a digital elevation model (DEM) was produced from contour lines of the study area in $\operatorname{ArcGIS}$ 10.1 software. An elevation (ELVTN) map was reproduced using DEM. ELVTN of the district ranges from $400 \mathrm{~m}$ to $1,923 \mathrm{~m}$ above sea level and contained $470 \times 279$ cells 
with horizontal and vertical resolution of $100 \mathrm{~m}$ and $100 \mathrm{~m}$, respectively. Topographic position index (TPI), aspect $(A S P C T)$, and slope degree (SLOPE) maps were derived by ELVTN. After that, landscape was classified into slope position by using ELVTN and TPI. Five slope position categories were generated: name of valley (VALLEY), toe slope (LSLOPE), midslope (MSLOPE), upper slope (USLOPE), and ridges (RIDGE) [34]. Six bedrock types were determined during inventory studies and coded as ALVM (alluvium), LMSTN (limestone), OPHME (ophiolitic melange), OTHBED (other bedrocks: sandstone-mudstone, pebble stone-sandstone, pebble stone, serpentinite, argillaceous limestone), SCHST (schist), and VOLSED (volcanic sediment). A lithology map of in the district was provided by the Mineral Research and Exploration General Directorate. Finally, by using each cell of aspect and slope value of the study area, a HEATIN map of the study area was derived from Equation 1.

\section{Statistical Analysis}

The generalized additive model $(G A M)$ was performed to determine the relationship between environmental variables and potential distribution of brutian pine. GAM is a non-parametric extension of the generalized linear model and a non-parametric smoothing function [3536]. Distribution of brutian pine was carried out within generalized regression analysis and spatial prediction (GRASP) in $S$-Plus 6.1. GRASP is an extension of obtaining spatial distribution of target species by means of GAM [37-39]. A quasi-binomial model was selected for brutian pine presence-absence data. ANOVA (F test) of quasi model was used as the statistical method. Model validation and performance were evaluated by a receiver operating characteristics $(R O C)$ curve.

\section{Results}

In this study, for the purpose of producing the potential distribution model and map of brutian pine, presence-absence data of brutian pine were collected from 453 sample plots. Potential distribution of brutian pine was carried out using the GAM. BIOI, BIO12, ELVTN, HEATIN, and BEDFOR variables that were included in the distribution of the brutian pine model. All contribution rates of statistically significant variables are given in Fig. 1. According to Fig. 1, the drop in explained deviance for ELVTN, BIO1, BIO12, HEATIN, and $B E D F O R$ variables contributed to $11.10 \%, 16.14 \%$, $48.82 \%, 22.42 \%$, and $12.97 \%$, respectively. Explained deviance for potential contribution (alone) of ELVTN, BIO1, BIO12, HEATIN, and BEDFOR were found to be $119.33,106.64,150.62,26.83$, and 37.30, respectively.

A possible formula for the final model is:

$$
\begin{gathered}
\mathrm{s}(E L V T N, 4)+\mathrm{s}(H E A T I N, 4)+B E D F O R \\
+\mathrm{s}(B I O 1,4)+\mathrm{s}(B I O 12,4)
\end{gathered}
$$

...where $\mathrm{s}$ is the spline smoother and 4 is degrees of freedom (df) for the spline smoother.

The partial response curve of environmental variables is given in Fig. 2. According to ELVTN's response curve, a negative correlation was found between brutian pine and elevation. Heat index was positively correlated with brutian pine. Furthermore, schist and limestone, which are bedrock formations, were preferred more than

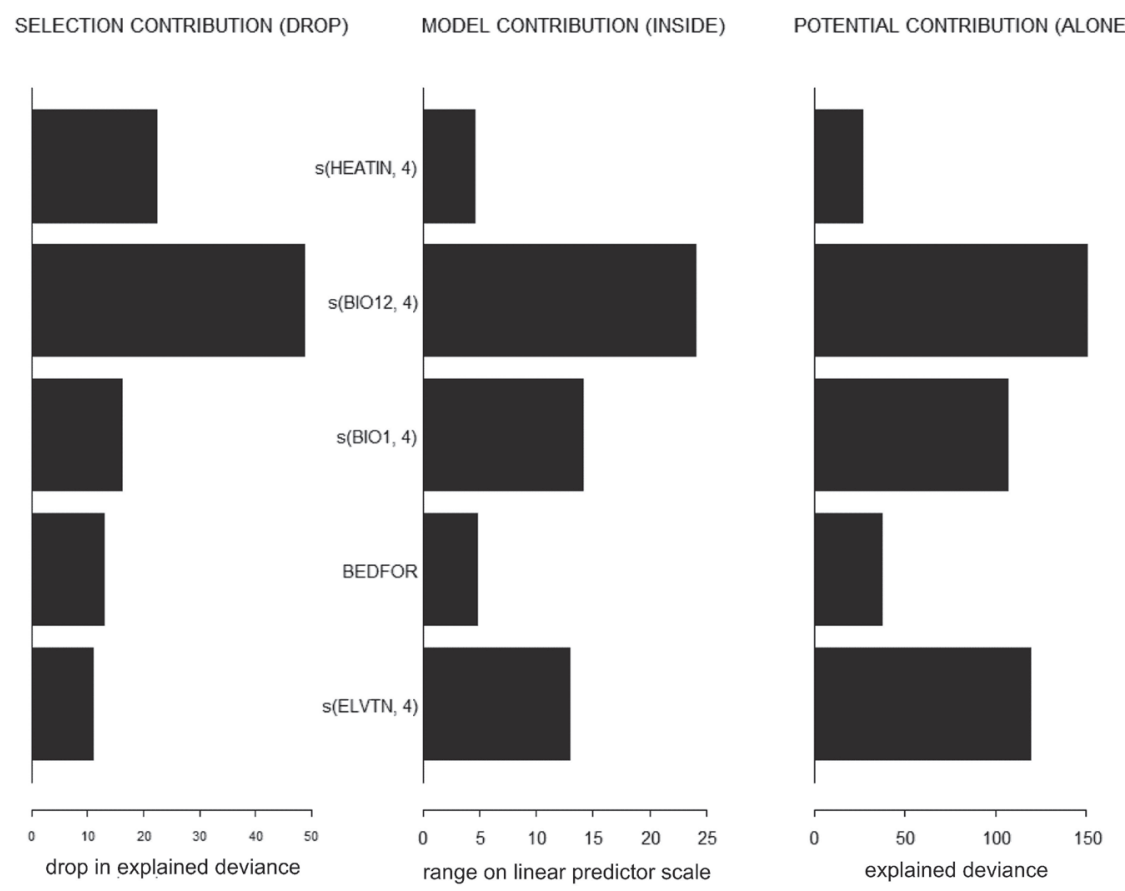

Fig. 1. Contributions of selected environmental variables to the modeling red pine potential distribution. 

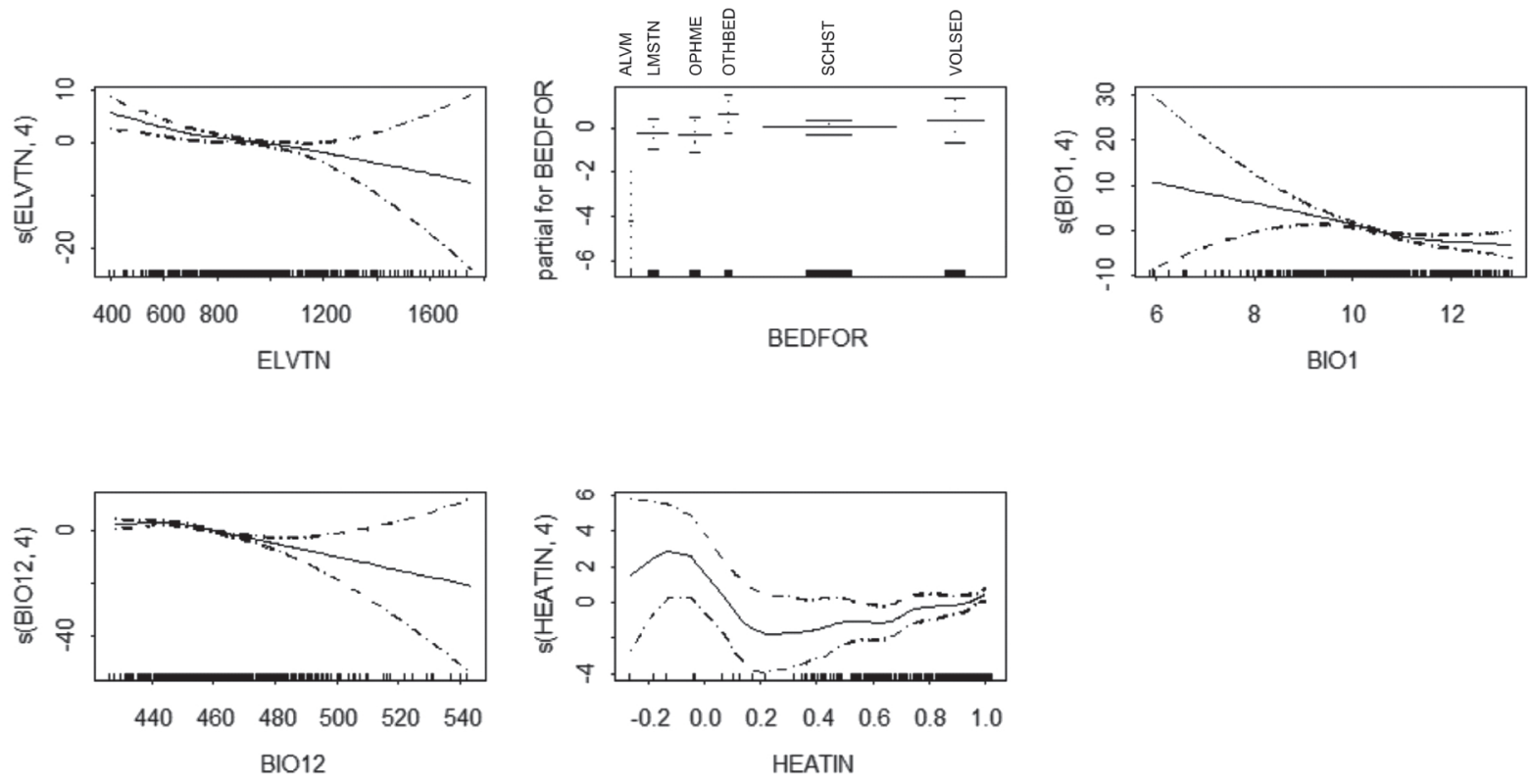

Fig. 2. Response curves of red pine.

other parent materials by brutian pine. Lastly, for both variables, $\mathrm{BIOI}$ and $\mathrm{BIO12}$, a negative correlation was determined. The histograms are shown in which areas are potentially more suitable for target species (Fig. 3). The potentially suitable area preference of brutian pine in the study area ranged from approximately $400 \mathrm{~m}$ to $806 \mathrm{~m}$ and schist and limestone bedrock formations were more preferred than others. In addition, resulting values for heat index were found above 0.87 . Finally, while values of $\mathrm{BIOl}$ changed between $11.1^{\circ} \mathrm{C}$ and $12.5^{\circ} \mathrm{C}$, values of BIO12 ranged from 428 to $440 \mathrm{~mm}$.

Both validation value (ROC) and cross-validation value (cvROC) were found to be 0.908 and 0.859 , respectively (Fig. 4). The results of ROC and cvROC are observed as relatively approximate values.

Finally, a potential distribution map file of brutian pine was performed by GRASP. This map was visualized using of ArcMap 10.1 software (Fig. 5).

\section{Discussion and Conclusions}

This study was conducted to determine the potential distribution area of brutian pine in the Aydinca District. The GAM showed that variables of BIO1, BIO12, ELVTN, HEATIN, and BEDFOR played an essential role in the

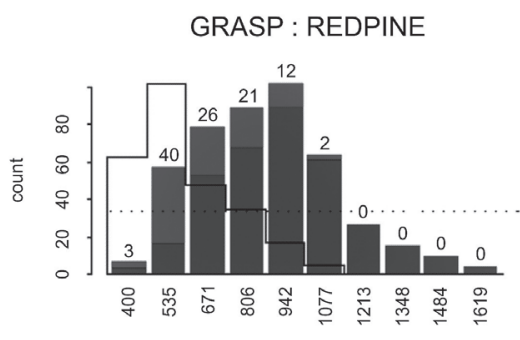

ELVTN

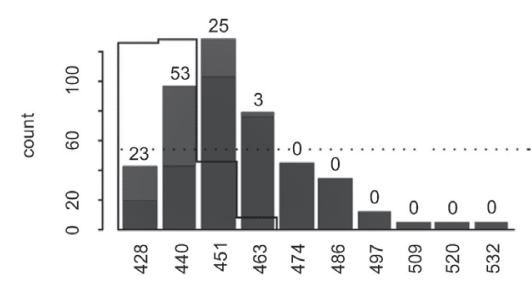

$\mathrm{BIO} 12$
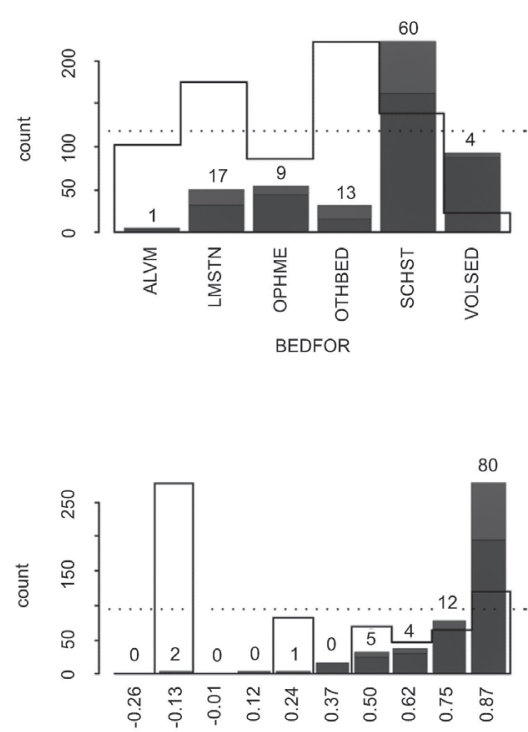

HFATIN

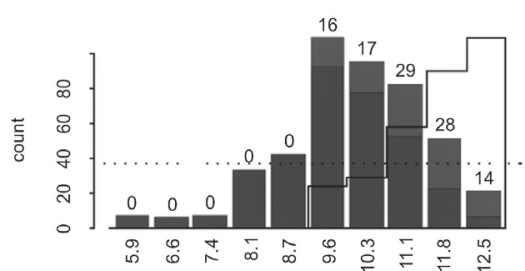

$\mathrm{BIO1}$

Fig. 3. Histograms of the predictor variables to the modeling of red pine distribution. 

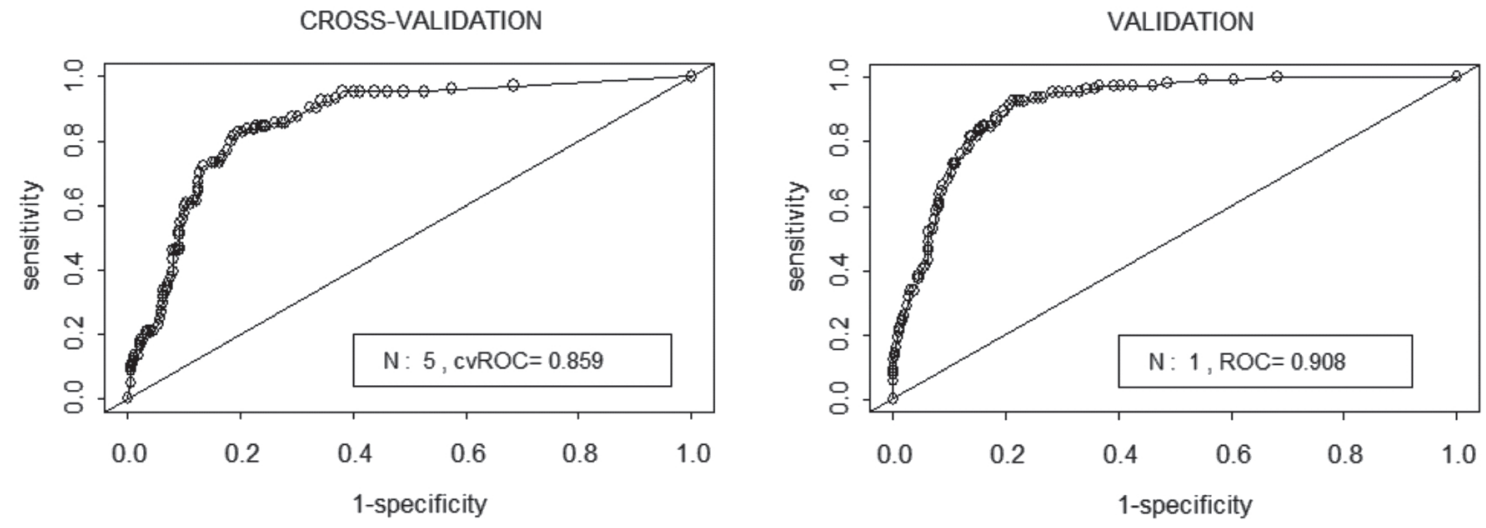

Fig. 4. Validation of the resulting model. AUC values for cvROC and ROC.

potential distribution of brutian pine in the Aydinca district.

As a result of this study, although the potential distribution of brutian pine in the district was found to range between elevations of approximately 400 and 806 $\mathrm{m}$, brutian pine was found to occur at elevations ranging from roughly 400 to $1,077 \mathrm{~m}$. It is known that distribution of many tree species in Turkey is generally related to altitude $[38,40]$. In this study, we obtained a similar correlation between altitude and distribution of brutian pine. Whereas some tree species in Aydinca such as black pine and scotch pine were distributed at higher altitudes, brutian pine was located more at lower elevations than these other species. On the other hand, there is also a high correlation between altitude and climate. Brutian pine was found in the study area where annual mean temperature is $11-12.5^{\circ} \mathrm{C}$ and annual mean precipitation is $428-439 \mathrm{~mm}$. But distribution of brutian pine was restricted due to the fact that temperature gradually is reduced above 1,100 m elevation. That is to say, Aydinca is located between the Yeşilırmak and Kelkit rivers in the backward part of the middle Black Sea in Turkey where a sub humid-semiarid climate prevails. Annual mean precipitation in these areas are less than $500 \mathrm{~mm}$ [41]. Besides, annual mean temperature in the part of the depression area is higher than $12^{\circ} \mathrm{C}$ [42]. On the other hand, the depression area located in the backward region of the middle Black Sea in Turkey is prevented both from frost and low temperatures during winter, while high temperatures are able to arise in this area during summer [43]. Due to this situation, potential distribution areas for brutian pine were locally formed by suitable site factors in the district.

Parent materials were found as another important factor that effects the distribution of brutian pine. Mainly schist parent material and partly limestone affected the potential distribution of the species in the district. Contrary to this situation, especially valley or plain areas composed of alluvium bedrock were determined to be unsuitable for potential distribution of brutian pine. It has been pointed out that schist and limestone parent material are covered around Abacı, Aynalı Yaylası, Avşar

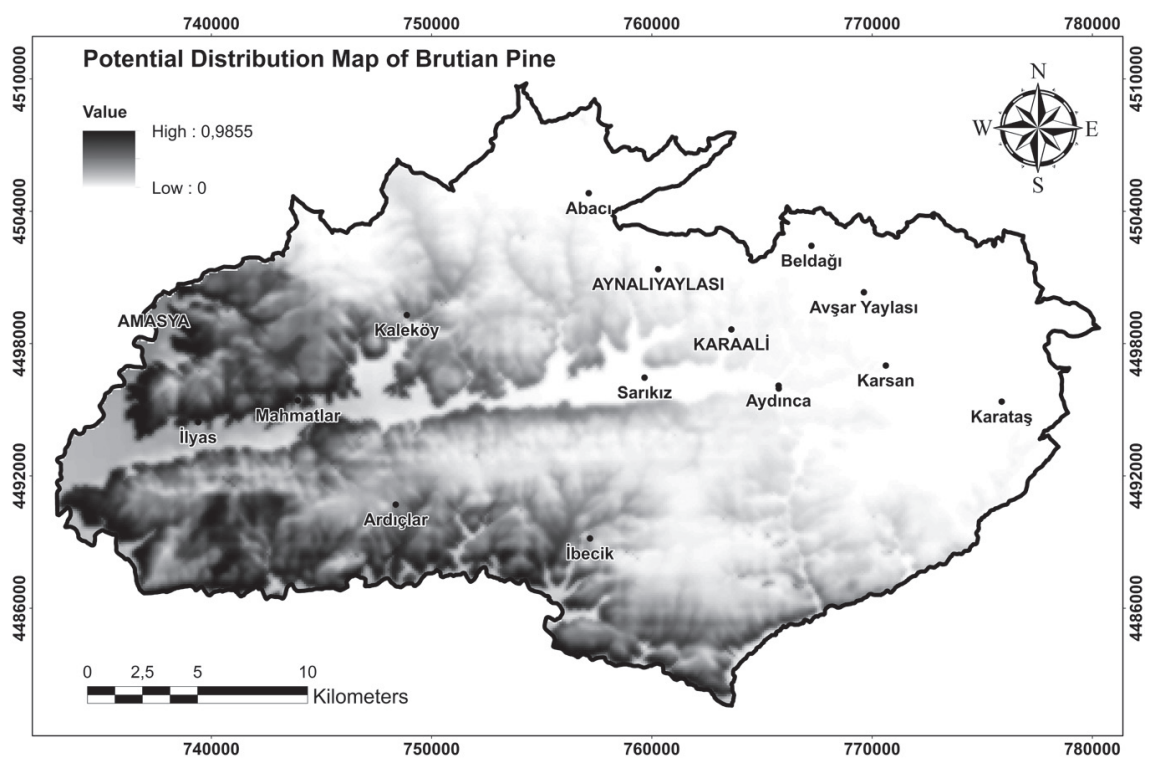

Fig. 5. Potential distribution map of red pine. 
Yaylası, and Karataş ve Aydınca in the study area. As said above, these locations were expected to be more suitable areas for the potential distribution of brutian pine. However, it was shown that these locations in the district were unsuitable areas for brutian pine. Due to the fact that these areas are higher than $1,100 \mathrm{~m}$, we think that the potential distribution of brutian pine in these areas is restricted depending on the altitude and climate relationship. This is to say, although brutian pine showed sensitivity to parent materials in the inner part of the middle Black Sea region, it was first adapted to climate conditions and hence maintained potential distribution in these local climate areas. It is known that the main distribution of brutian pine ranges from different parent materials such as schist, conglomerate, serpentine, marn, basalt, and flysch $[28,44]$. However, brutian pine prefers more clay schist, marn, and limestone, plus sandstone parent materials in the Mediterranean region. On the other hand, it was expressed that while brutian pine saw its best growth on limestone and schist parent materials, it showed bad growth performance when growing on volcanic rocks and siliceous materials [43-44]. When the obtained results are compared to other research from literature, it was determined that parent materials affected distribution of brutian pine similarly. Finally, as a result of static assessment, heat index was found to be another important factor for potential distribution of brutian pine. Heat index is transformed to aspect and slope cell values by using a formula and represented solar parameters in the environment. As is known, brutian pine is a typically shade-intolerant tree and more lightdemanding than many other conifer tree species [45]. As mentioned previously, local areas that show a higher solar radiation index were also determined to be more suitable potential distribution areas for brutian pine. In the same way, Atalay [41] has stated that brutian pine throughout the tectonic depressions in the inner parts of the middle Black Sea region in Turkey were distributed depending upon higher solar radiation.

In conclusion, areas located in the inner parts of the middle Black Sea region in Turkey formed local suitable areas for brutian pine, which is supported by our results. It is very important to protect the ecosystem diversity in the district with areas having suitable climate factors and parent materials known to have potential distribution for brutian pine in the middle Black Sea region in Turkey. Lastly, as a result of future climate change, it will become more important to determine the ecological characteristics of the species that are distributed in such local areas.

\section{Acknowledgements}

We thank Süleyman Demirel University Scientific Research Projects Coordination Unit (SDÜ BAP) for providing financial support to this project (No. BAPKB - 13548-YL1-13).

\section{Conflict of Interest}

The authors declare no conflict of interest.

\section{References}

1. GUISAN A., ZIMMERMANN N.E. Predictive habitat distribution models in ecology. Ecological modelling, 135 (2), 147, 2000.

2. ELITH J., LEATHWICK J.R. Species distribution models: ecological explanation and prediction across space and time. Annual review of ecology, evolution, and systematics, 40, 677, 2009.

3. MARMION M., PARVIAINEN M., LUOTO M., HEIKKINEN R. K., THUILLER W. Evaluation of consensus methods in predictive species distribution modelling. Diversity and distributions, 15 (1), 59, 2009.

4. HANSPACH J., KÜHN I., SCHWEIGER O., POMPE S., KLOTZ S. Geographical patterns in prediction errors of species distribution models. Global Ecology and Biogeography, 20 (5), 779, 2011.

5. LINDER H.P., BYKOVA O., DYKE J., ETIENNE R.S., HICKLER T., KÜHN I., MARION G., OHLEMÜLLER R., SCHYMANSKI S.J., SINGER A. Biotic modifiers, environmental modulation and species distribution models. Journal of Biogeography, 39 (12), 2179, 2012.

6. HAMANN A., AITKEN S.N. Conservation planning under climate change: accounting for adaptive potential and migration capacity in species distribution models. Diversity and Distributions, 19 (3), 268, 2013.

7. PRADERVAND J.-N., DUBUIS A., PELLISSIER L., GUISAN A., RANDIN C. Very high resolution environmental predictors in species distribution models: Moving beyond topography? Progress in Physical Geography, 38 (1), 79, 2014.

8. FRANKLIN J. Mapping species distributions: spatial inference and prediction. 2010.

9. RICHARDSON D.M., WHITTAKER R.J. Conservation biogeography-foundations, concepts and challenges. Diversity and Distributions, 16 (3), 313, 2010.

10. FEELEY K.J., SILMAN M.R. Keep collecting: accurate species distribution modelling requires more collections than previously thought. Diversity and Distributions, 17 (6), 1132, 2011

11. NAIMI B., SKIDMORE A.K., GROEN T.A., HAMM N.A. Spatial autocorrelation in predictors reduces the impact of positional uncertainty in occurrence data on species distribution modelling. Journal of Biogeography, 38 (8), 1497, 2011.

12. ÖZKAN K., SENTÜRK Ö., MERT A., NEGIZ M.G. Modeling and mapping potential distribution of Crimean juniper (Juniperus excelsa Bieb.) using correlative approaches. Journal of environmental biology, 36 (1), 9, 2015.

13. RÖDDER D., LÖTTERS S. Potential distribution of the alien invasive brown tree snake, Boiga irregularis (Reptilia: Colubridae). Pacific Science, 64 (1), 11, 2010.

14. BRAMBILLA M., FICETOLA G.F. Species distribution models as a tool to estimate reproductive parameters: a case study with a passerine bird species. Journal of Animal Ecology, 81 (4), 781, 2012.

15. AHMADI M., KABOLI M., NOURANI E., SHABANI A.A., ASHRAFI S. A predictive spatial model for gray 
wolf (Canis lupus) denning sites in a human-dominated landscape in western Iran. Ecological research, 28 (3), 513, 2013.

16. RAMESHPRABU N., SWAMY P. Prediction of environmental suitability for invasion of Mikania micrantha in India by species distribution modelling. Journal of Environmental Biology, 36 (3), 565, 2015.

17. SÁNCHEZ-GARCIA F.J., GALIÁN J., GALLEGO D. Distribution of Tomicus destruens (Coleoptera: Scolytinae) mitochondrial lineages: phylogeographic insights and niche modelling. Organisms Diversity \& Evolution, 15 (1), 101, 2015.

18. ÖZKAN K., MERT A., ŞENTÜRK Ö. Estimation of Potential Distribution of Non-Wood Trading Species Richness Using Classification and Regression Tree Technique: A case study from Lakes district, Turkey. II. International Non-Wood Forest Products Symposium, Eds: Fakir, H., Dutkuner, İ., Gürlevik, N., Sarıkaya, Babalık, A., 238, 2011.

19. ÖZKAN K., ŞENTÜRK Ö. The Application of Group Discrimination Techniques to Predict The Potential Distribution Of Turbentine Tree. Internatinal Scientific Conference People Buildings And Environment, 7, 2012.

20. ÖZKAN K. Using the non-parametric classifier CART to model lebanon cedar (Cedrus libani A. Rich) distribution in a mountain Mediterranean Forest District. Polish Journal of Environmental Studies, 22 (2), 495, 2013.

21. GÜLSOY S., ŞENTÜRK Ö. Modeling the Potential Geographical Distribution of Anatolian Black Pine (Pinus nigra Arnold. subsp. pallasiana Lamb. Holmboe) in the Inner Parts of Central Black Sea Region. 4th International Geography Symposium (Edited by Recep EFE and İsa Cürebal), 288, 2016.

22. ŞENTÜRK Ö., GÜLSOY S., TÜMER İ. Relationship between distribution of Turkey oak (Quercus cerris L.) and site factors in Aydinca district forests of Amasya, Turkey. The Journal of Graduate School of Natural and Applied Sciences of Mehmet Akif Ersoy University, 5 (2), 13, 2014.

23. GÜLSOY S., ŞENTÜRK Ö., KARAKAYA F. Modeling the potential distribution of Turkish oak (Quercus cerris L.) in Kunduz district (Vezirköprü), Turkey. Süleyman Demirel University Journal of Natural and Applied Sciences, 20 (2), 2016.

24. ÖZÇELIK R., KARAER K. Development of merchantable volume equations for natural brutian pine and black pine stands in Eğirdir District. Journal of the Faculty of Forestry Istanbul University, 66 (1), 59, 2016.

25. ÖZKAN K., KUZUGÜDENLİ E. The relations between site index of brutian pine (Pinus brutia Ten.) and ecological site factors in Sütçüler district from the Mediterranean region. Turkish Journal of Forestry, 1 (1), 16, 2010.

26. KARATEPE Y., ÖZÇELIK R., GÜRLEVIK N., YAVUZ H., KIRIŞ R. Ecological evaluation of vegetation structure in Turkish red pine forests (Pinus brutia Ten.) in different sites of western Mediterranean region of Turkey. Turkish Journal of Forestry, 15, 1-8, 2014.

27. ÇELIK H., ÖZKAN K. ARelationships between some environmental characteristic and site index of brutian pine (Pinus brutia Ten.) in the Ovac1k mountain district, Antalya. Süleyman Demirel University Journal of Natural and Applied Sciences, 19 (2), 2015.

28. ARBEZ M. Distribution, ecology and variation of Pinus brutia in Turkey. Forest Genetic Resources, 3, 0-7, 1974.

29. KANDEMIR G., KAYA Z., TEMEL F., ÖNDE S. Genetic variation in cold hardiness and phenology between and within Turkish red pine (Pinus brutia Ten.) populations: implications for seed transfer. Silvae Genet, $\mathbf{5 9 ,}, 49,2010$.

30. TÜMER İ. The Relationships Between the Distribution of the Main Tree Species and Site Factors in the Forests of the Aydinca District (Amasya). Suleyman Demirel University Graduate School of Natural and Applied Science, Master Thesis, 113, 2015.

31. PARKER K.C. Environmental relationships and vegetation associates of columnar cacti in the northern Sonoran Desert. Vegetatio, 78 (3), 125, 1988.

32. OLSSON P.A., MARTENSSON L.-M., BRUUN H.H. Acidification of sandy grasslands-consequences for plant diversity. Applied Vegetation Science, 12 (3), 350, 2009.

33. HIJMANS R.J., CAMERON S.E., PARRA J.L., JONES P.G., JARVIS A. Very high resolution interpolated climate surfaces for global land areas. International journal of climatology, 25 (15), 1965, 2005.

34. TAGIL S., JENNESS J. GIS-based automated landform classification and topographic, landcover and geologic attributes of landforms around the Yazoren Polje, Turkey. Journal of Applied Sciences, 8, 910, 2008.

35. GUISAN A., EDWARDS T.C., HASTIE T. Generalized linear and generalized additive models in studies of species distributions: setting the scene. Ecological modelling, 157 (2), 89, 2002.

36. MOISEN G.G., FREEMAN E.A., BLACKARD J.A., FRESCINO T.S., ZIMMERMANN N.E., EDWARDS JR T.C. Predicting tree species presence and basal area in Utah: a comparison of stochastic gradient boosting, generalized additive models, and tree-based methods. ecological modelling, 199 (2), 176, 2006.

37. LEHMANN A., OVERTON J.M., LEATHWICK J.R. GRASP: generalized regression analysis and spatial prediction. Ecological modelling, 157 (2), 189, 2002.

38. ÖZKAN K. Identification of driving factors for presence of endemic species in the Aglasun district of the Mediterranean Region, Turkey. Pol. J. Ecol, 60 (2), 291, 2012.

39. GÜLSOY S., ÖZKAN K. Determination of environmental factors and indicator plant species for site suitability assessment of Crimean Juniper in the Acipayam District, Turkey. Sains Malaysiana, 42 (10), 1439, 2013.

40. OZKAN K., SENOL H., GULSOY S., MERT A., SUEL H., ESER Y. Vegetation-environment relationships in Mediterranean mountain forests on limeless bedrocks of southern Anatolia, Turkey. Journal of Environmental Engineering and Landscape Management, 17 (3), 154, 2009.

41. ATALAY I. Forest composition changes with competition in the norhern part of Turkey. European Scientific Journal, 2, 364, 2014.

42. ATALAY I., EFE R., ÖZTÜRK M. Ecology and Classification of Forests in Turkey. Procedia - Social and Behavioral Sciences, 120, 788, 2014.

43. ATALAY İ., SEZER İ., ÇUKUR H. Kızılçam (Pinus brutia Ten.) ormanlarının ekolojik özellikleri ve tohum nakli açısından bölgelere ayrılması [In Turkish]. Orman Ağaçları ve Tohumları Islah Araştırma Müdürlüğü, Yay. No: 6, Ankara. 1998.

44. ATALAY İ., EFE R. Türkiye Biocoğrafyası [In Turkish]. Meta Basım Matbaacılık Hizmetleri, İzmir, 1, 536, 2015.

45. SAATÇİĞLU F., PAMAY B. The importance of Pinus brutia in the development of Adana region and its silviculture. Journal of the Faculty of Forestry Istanbul University, 12 (2), 88, 1962. 
